\title{
Accumulation of the lipophilic environmental contaminant lindane in metacercariae of Bucephaloides gracilescens (Trematoda, Bucephalidae) in the central nervous system of bullrout Myoxocephalus scorpius
}

\author{
A. Ruus ${ }^{1,2, *}$, J. U. Skaare ${ }^{2,3}$, K. Ingebrigtsen ${ }^{3}$ \\ ${ }^{1}$ Department of Marine Zoology and Marine Chemistry, Institute of Biology, University of Oslo, PO Box 1064, Blindern, 0316 Oslo, Norway \\ ${ }^{2}$ National Veterinary Institute, PO Box 8156 dep., 0033 Oslo, Norway \\ ${ }^{3}$ Department of Pharmacology, Microbiology and Food Hygiene, Norwegian School of Veterinary Science, PO Box 8146 dep., \\ 0033 Oslo, Norway
}

\begin{abstract}
Bucephaloides gracilescens is a common parasite in the intestine of the angler fish Lophius piscatorius, and the metacercariae have been recorded from a number of gadoid intermediate hosts. In a toxicokinetic study of lindane ( $\gamma$-hexachlorocyclohexane) in bullrout Myoxocephalus scorpius, metacercariae of B. gracilescens were found in the central nervous system (CNS). Furthermore, the metacercariae accumulated concentrations of lindane that were higher than in the surrounding CNS tissue. This is the first report of metacercariae of $B$. gracilescens in bullrout. In addition the present results contribute knowledge of the disposition of an important environmental contaminant in the metacercarial stage of a trematode that has been pointed out as a promising sentinel species of pollution in the marine environment.
\end{abstract}

KEY WORDS: Bucephaloides gracilescens $\cdot$ Myoxocephalus scorpius $\cdot$ Lindane $\cdot \gamma$-hexachlorocyclohexane $\cdot$ Metacercariae

Resale or republication not permitted without written consent of the publisher

The life cycle of Bucephaloides gracilescens was described by Matthews (1974). It is a common gasterostome parasite in the intestine of the angler fish Lophius piscatorius (Brinkmann 1957, Halton \& Johnston 1982a), its only true final host. The primary mollusc host is the bivalve Abra alba, but other bivalves most likely also act as first hosts (Køie 1984, 2000). The metacercariae have been recorded from a number of gadoid fish (Johnston \& Halton 1981, Karlsbakk 1995), and have attracted much attention because of their occurrence in the central nervous system (CNS) and on major peripheral nerves (Dawes 1947, MacKenzie 1991). This is the first report of metacercariae of $B$. gracilescens in bullrout Myoxocephalus scorpius.

Bullrouts were caught in coastal waters at a depth of 2 to $6 \mathrm{~m}$, near shore in the Hvaler Archipelago in

*E-mail: anders.ruus@niva.no south-eastern Norway, to conduct a toxicokinetic study of orally administered organochlorine contaminants, including the insecticide lindane ( $\gamma$-hexachlorocyclohexane) (Ruus et al. 2001). The study was performed in 1998 (September to October) at the Institute of Biology, University of Oslo. Fish of both sexes were held in a fibreglass tank (500 l) and acclimated for $>2 \mathrm{wk}$ in a $12 \mathrm{~h}$ light:12 h dark cycle before the experiment. The water temperatures and salinities were 14 to $14.3^{\circ} \mathrm{C}$ and 31 to $33.5 \%$, respectively. $\gamma$-[U- $\left.{ }^{14} \mathrm{C}\right]$ hexachlorocyclohexane $\left(64 \mathrm{mCi} \mathrm{mmol}^{-1}\right.$; Amersham Life Sciences, Little Chalfont, UK) was diluted with non-labelled lindane (Promochem GmbH, Wesel, Germany) and dissolved in commercial cod liver oil (Möller's, Oslo, Norway) $\left(500 \mu \mathrm{g} \mathrm{ml}^{-1}\right)$ to give a specific activity of $33 \mu \mathrm{Ci}$ $\mathrm{ml}^{-1}$. Small pellets (Ewos, Bergen, Norway) were coated with the test solution and administered orally to 6 bullrouts through a stomach tube (Horsberg 1994). The individual dose was $1 \mu \mathrm{g}$ lindane $\mathrm{g}^{-1}$ body weight. After exposure, the fish were transferred to an aerated glass tank (38 l) supplied with running seawater (0.2 l $\min ^{-1}$ ) and with the same holding conditions as the fibreglass tank. Two fish were euthanized with an overdose of benzocaine in water 3,6 and $12 \mathrm{~d}$ after exposure. They were immediately frozen in liquid nitrogen and stored at $-20^{\circ} \mathrm{C}$ before whole-body autoradiography was performed as described by Ullberg (1977).

Whole-body autoradiograms of the bullrouts showed lindane-related radioactivity in the liver and CNS $3 \mathrm{~d}$ after exposure (Ruus et al. 2001). The highest concentrations, however, were found in excretory organs such as the gall bladder, urine bladder and intestine. Twelve days after exposure, the radioactivity was visible only in bile. Interestingly, autoradiograms also revealed 
radioactive hot spots in the CNS $3 \mathrm{~d}$ after exposure (Fig. 1a). These spots corresponded to cyst-like structures in the whole-body sections. Radioactivity persisted in these structures through Day 6 and was not detectable at Day 12. An untreated bullrout was euthanized and the brain was excised (Fig 1b) and fixed in $4 \%$ formaldehyde in phosphate buffer ( $\mathrm{pH}$ 7.4). The tissue was stained with haematoxylin and eosin for microscopic evaluation. The cysts were identified as metacercariae of Bucephaloides gracilescens (Fig. 1c). A total of 13 bullrouts were then examined, of which 11 were infected.

Halton \& Johnston (1982b) showed that encysted larvae of Bucephaloides gracilescens retain communication with the surrounding host tissue, since substrates $\left(\left[{ }^{3} \mathrm{H}\right]\right.$ thymidine, $\left[{ }^{3} \mathrm{H}\right]$ tyrosine and $\left[{ }^{3} \mathrm{H}\right]$ proline) were absorbed across the cyst wall and subsequently incorporated by the metacercaria. Considering that lindane is a lipophilic compound $\left(\log K_{\text {ow }}=3.69 ;\right.$ de Bruijn et al. 1989), its accumulation in the metacercariae suggests that these contain lipids. Little is known about the content and function of lipids in digenean larvae in general (Marsit et al. 2000), but lipids have been observed in the tissues of some metacercariae (Ginetsinskaya 1961, Žďárská 1964, Marsit et al. 2000), including Labratrema minimus, another member of the family Bucephalidae (Faliex 1991). Lipids in metacercariae may serve as a supplementary reserve of energy producing material (under aerobic conditions) or it may be derived from incomplete breakdown of carbohydrates as a by-product of the process whereby the animal obtains its basic energy requirements under anaerobic conditions (Ginetsinskaya 1961). Von Brand (1946) refers to this as 'excretory fat'.

The finding that most of the lindanerelated radioactivity was found in excre-
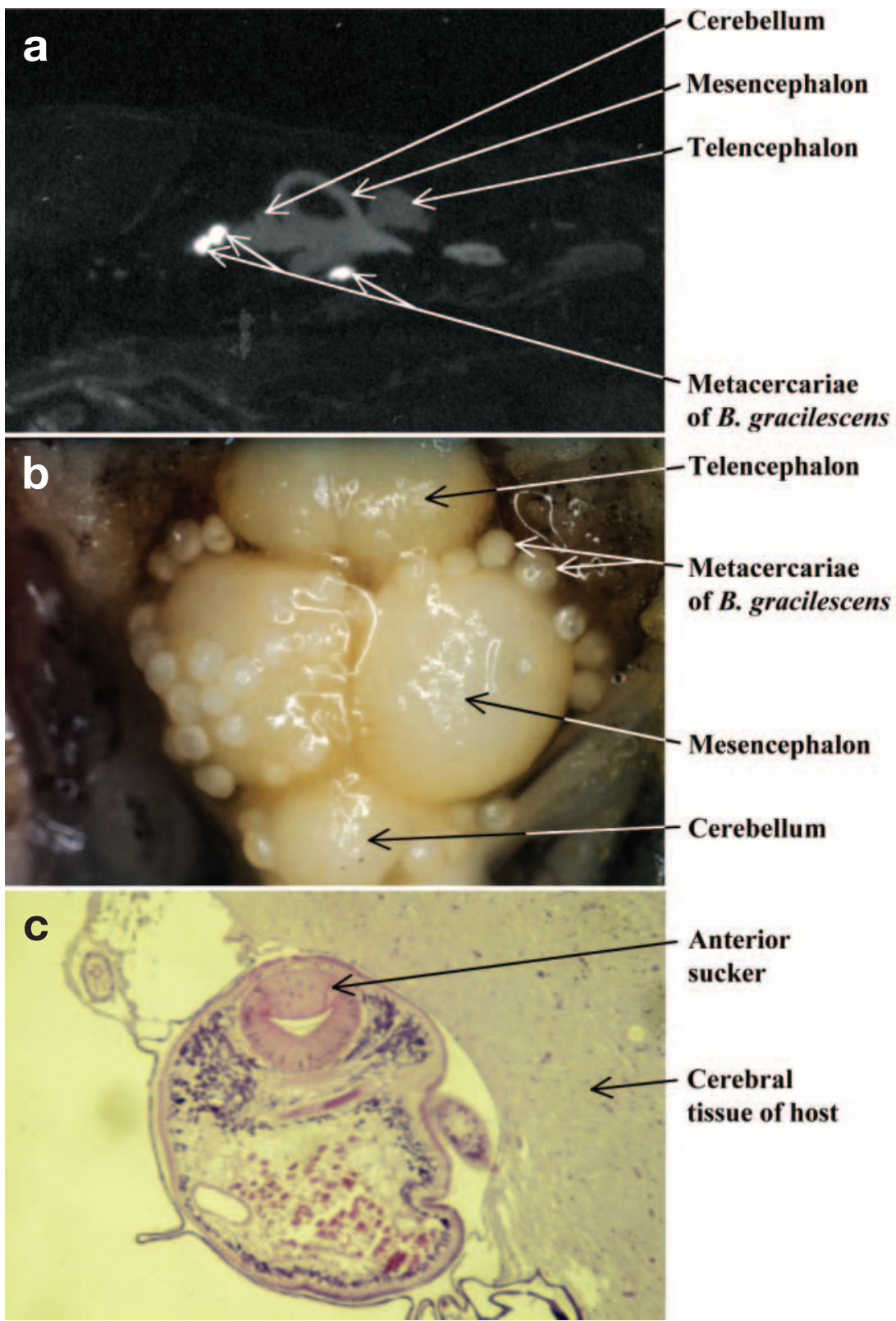

Fig. 1. (a) Autoradiogram of a sagittal section from the central nervous system (CNS) of a bullrout Myoxocephalus scorpius (white areas correspond to high concentrations of $\gamma-\left[{ }^{14} \mathrm{C}\right]$ hexachlorocyclohexane); (b) dorsal view of the CNS of a bullrout; (c) section of a metacercaria of Bucephaloides gracilescens from the CNS of a bullrout. Haematoxylin and eosin stain

tory organs of the host $3 \mathrm{~d}$ after exposure indicates that the lindane concentrations in other organs, such as the CNS, may have been higher before this sampling time. This suggestion is supported by Görge \& Nagel (1990), who discovered that juvenile zebrafish Brachydanio rerio exposed to (water-borne) lindane eliminated more than $90 \%$ of the compound at steady state, within $24 \mathrm{~h}$, when transferred to pesticide-free running water. According to this, it is likely that lindane entered the metacercariae by diffusion through the cyst wall from the adjacent host tissues when these contained higher lindane concentrations. Three days after exposure, the host had eliminated much of the lindane, while the elimination rates from the metacercariae were lower.

According to MacKenzie (1999), there are good reasons for focusing on helminth parasites in the search for highly sensitive indicators of pollution in the marine environment, and Bucephaloides gracilescens has 
been pointed out as a promising sentinel species (MacKenzie et al. 1995). Owing to their complex life cycles with different stages having widely differing requirements, trematodes may be adversely affected by even minor changes in the environment. Effects of environmental pollution on helminth parasites are most often described in terms of viability and infectivity (reviewed by MacKenzie et al. 1995). The present report contributes to the basic knowledge on the disposition of an important environmental contaminant in the metacercarial stage of B. gracilescens. The toxicological significance of the observations presented here, however, is not known.

Acknowledgements. We thank the Iversens and the Jensens for their helpful effort to collect bullrouts. Tor Andreas Bakke was of much help identifying the metacercariae. We also thank Inger Lise Gross for cryosectioning and histological preparation, and Inger Catrinius and Trygve Poppe for photographic processing.

\section{LITTERATURE CITED}

Brinkmann A Jr (1957) Fish trematodes from Norwegian waters IIa. The Norwegian species of the orders Aspidogastrea and Digenea (Gasterostomata). Univ Bergen Arbok Naturvitensk Rekke 4:1-29

Dawes B (1947) The trematoda of British fishes. The Ray Society, London

de Bruijn J, Busser F, Seinen W, Hermens J (1989) Determination of octanol/water partition coefficients for hydrophobic organic chemicals with the 'slow-stirring' method. Environ Toxicol Chem 8:499-512

Faliex E (1991) Ultrastructural study of the host-parasite interface after infection of two species of teleosts by Labratrema minimus metacercariae (Trematoda, Bucephalidae). Dis Aquat Org 10:93-101

Ginetsinskaya TA (1961) Dynamics of fat deposition in the course of trematode life cycles. Dokl Akad Nauk SSSR Biol Sci Sect 136-141:663-665 (English translation)

Görge G, Nagel R (1990) Kinetics and metabolism of ${ }^{14} \mathrm{C}$ lindane and ${ }^{14} \mathrm{C}$-atrazine in early life stages of zebrafish (Brachydanio rerio). Chemosphere 33:449-451

Halton DW, Johnston BR (1982a) Occurrence and infectivity of Bucephaloides gracilescens (Trematoda: Bucephalidae) in angler fish from the Irish Sea. Ir Nat J 20:526-531

Editorial responsibility: Wolfgang Körting,

Hannover, Germany
Halton DW, Johnston BR (1982b) Functional morphology of the metacercarial cyst of Bucephaloides gracilescens (Trematoda: Bucephalidae). Parasitology 85:45-52

Horsberg TE (1994) Experimental methods for pharmacokinetic studies in salmonids. Annu Rev Fish Dis 4:345-358

Johnston BR, Halton DW (1981) Occurrence of Bucephaloides gracilescens metacercariae in three species of gadoid fish. J Fish Biol 18:685-691

Karlsbakk E (1995) The occurrence of metacercariae of $\mathrm{Bu}$ cephaloides gracilescens (Digenea: Gasterostomata) in an intermediate host, the four-bearded rockling, Enchelyopus cimbrius (Gadidae). J Fish Biol 46:18-27

Køie M (1984) Digenetic trematodes from Gadus morhua L. (Osteichtyes, Gadidae) from Danish and adjacent waters, with special reference to their life-histories. Ophelia 23: $195-222$

Køie M (2000) Metazoan parasites of teleost fishes from Atlantic waters off the Faroe Islands. Ophelia 52:25-44

MacKenzie K (1991) Massive infections of cod, Gadus morhua L., in The Firth of Clyde with metacercariae of the digenean Bucephaloides gracilescens (Rudolphi, 1819). Bull Eur Assoc Fish Pathol 11:125-126

MacKenzie K (1999) Parasites as pollution indicators in marine ecosystems: a proposed early warning system. Mar Pollut Bull 38:955-959

MacKenzie K, Williams HH, Williams B, McVicar AH, Siddall $R$ (1995) Parasites as indicators of water quality and the potential use of helminth transmission in marine pollution studies. Adv Parasitol 35:85-144

Marsit CJ, Fried B, Sherma J (2000) Neutral lipids in cercariae, encysted metacercariae, and rediae of Zygocotyle lunata. J Parasitol 86:1162-1163

Matthews RA (1974) The life-cycle of Bucephaloides gracilescens (Rudolphi, 1819) Hopkins, 1954 (Digenea: Gasterostomata). Parasitology 68:1-12

Ruus A, Skaare JU, Ingebrigtsen K (2001) Disposition and depuration of lindane $(\gamma-\mathrm{HCH})$ and polychlorinated biphenyl-110 $\left(2,3,3^{\prime}, 4^{\prime}, 6\right.$-pentachlorobiphenyl) in cod (Gadus morhua) and bullrout (Myoxocephalus scorpius) after single oral exposures. Environ Toxicol Chem 20: $2377-2382$

Ullberg S (1977) The technique of whole-body autoradiography. Cryosectioning of large specimens. Sci Tools Spec Iss: $1-29$

von Brand T (1946) Anaerobiosis in invertebrates. Biodynamica Monogr 4:1-328

Ždárská Z (1964) Contribution to the knowledge of metabolic and morphological changes in the metacercariae Echinostoma revolutum (Fröhlich, 1802) Dietz, 1909 (Trematoda). Vestn Cesk Spol Zool 28:285-289

Submitted: January 2, 2001; Accepted: August 15, 2001

Proofs received from author(s): December 10, 2001 